\title{
POLISH CHILD MIGRANTS - PSYCHOLOGICAL PERSPECTIVE
}

\author{
Paulina Szydłowska \\ http://orcid.org/0000-0002-2196-9940 \\ Jagiellonian University, Kraków
}

\begin{abstract}
According to the Instituto Nacional de Estadistica, as of January 2017, there were 52.893 Polish people residing in Spain. Even though the Polish minority has been present in Spain since the 16th century, the community started to grow in the 1980s due to the influx of economic immigrants. In 2004, there were more than 800 children who had at least one parent of Polish origin. It can be said that those children belong to the second generation of Polish migrants. The Relative Acculturation Extended Model (RAEM) has been adapted to measure the acculturation of children and adolescents. It assumes that people undertake different acculturation strategies in different spheres of life. These spheres were divided into central and peripheral. This model also allows to distinguish real and ideal plane of acculturation. The comparative studies (Lopez-Rodriguez et al., 2014) conducted with a group of young people in Spain and Italy show that children and adolescents prefer to preserve their own culture in the central spheres, while adapting the culture of the host country in the peripheral spheres. The main research question of my paper is: What strategies of cultural adaptation according to the RAEM Model undertaken in peripheral spheres do children and youth of Polish origin mention in their narrations? Twelve people participated in the pilot study. One subgroup consisted of five children aged 10 to 15, who attend classes in a Polish school. Their parents constituted another subgroup. Four children had both parents of Polish descent, one child came from a mixed-race family: Spanish-Polish. As part of the study, 11 semi-in-depth interviews were conducted. The starting point of each conversation was a set list of questions based on the RAEM model, which each researcher could develop depending on the threads introduced by the examined person. The qualitative data collected in the pilot study of this group of Polish child immigrants show some preliminary results. It is difficult to assess the strategies undertaken by teenage immigrants in particular spheres. Firstly, the narrations of children about the adaptation strategies partly coincided with the Spanish-Italian quantitative ones, saying that in the peripheral spheres children adopt the culture of the host country. On the other hand, the behaviors described by young people can be understood as undertaking integration strategies because they go to Spanish schools and take part in Polish 'Saturday' classes, and maintain contact with both Spanish people and the Poles who live in Poland. In the sphere of peer relations, children narrate the differences between the real and the ideal planes. In the real plane, children say that they do not keep in touch with children from
\end{abstract}


Polish "Saturday" schools outside the school building, but in the ideal plane, they would like to be able to meet with them outside the school context. Parents and their acculturation strategies may have an impact on children's behaviors. To test this, in further studies, the acculturation strategies undertaken by parents should be additionally covered. Moreover, the factors which affect the undertaking of particular integration strategies should be found.

Keywords: migration, children, acculturation, adolescents, discrimination.

Migration is an important part of the contemporary social reality. People migrate for a variety of reasons - both voluntarily and forcedly. Around 65.3 million individuals were forcibly displaced worldwide at the end of 2015 as a result of persecution, conflict, generalized violence or human rights violations. ${ }^{1}$ Minors constituted a considerable number in these groups. In literature, information can be found about the directions of the migration of the Polish people over the years. For many years, children and young people have been omitted in the migration research. In this article, I would like to take a closer look at the cultural adaptation strategies undertaken in various spheres of life by Polish children living in Madrid and present some preliminary results based on the pilot study of its sister PhD research project.

\section{POLES ABROAD}

The main migration directions of the Polish people after World War II are Canada, the United States and West European countries such as the United Kingdom, France or Germany (GDR / West Germany). According to the Central Statistical Office, ${ }^{2}$ from 1966 to 2014, more people permanently emigrated from Poland than came to live there. After Poland's accession to the EU in 2004, the scale of migration of the citizens of the country increased significantly. According to the results of the estimates, ${ }^{3}$ at the end of 2016, there were around 2,515,000 Poles living temporarily outside Poland, 118,000 (4.7\%) more than in 2015. Most of them were staying in Europe (about $2,214,000$ in 2016), especially in EU member states (about 2,096,000). Among the EU countries, most Polish emigrants resided in Great Britain $(788,000)$, Germany $(687,000)$, the Netherlands $(116,000)$ and Ireland $(112,000)$. In 2016, there was a significant increase in the number of Poles staying in Great Britain and Germany - the

1 United Nations High Commissioner for Refugees, http://www.unhcr.org/globaltrends2016/ [access: 27.05.2019].

2 GUS, Główne kierunki emigracji i imigracji w latach 1966-2014 (migracje na pobyt stały), https://stat.gov.pl/obszary-tematyczne/ludnosc/migracje-zagraniczne-ludnosci/glowne-kierunkiemigracji-i-imigracji-w-latach-1966-2014-migracje-na-pobyt-staly,4,1.html/ [access: 27.05.2019].

3 GUS, Informacja o rozmiarach i kierunkach czasowej emigracji z Polski w latach 2004-2016, Warszawa 2017, p. 1, https://stat.gov.pl/obszary-tematyczne/ludnosc/migracje-zagraniczne-ludnosci/ informacja-o-rozmiarach-i-kierunkach-emigracji-z-polski-w-latach-20042016,2,10.html [access: 27.05. 2019]. 
main destination countries of emigration from Poland in recent years. According to the National Institute of Statistics in Spain (Instituto Nacional de Estadística - INE), in 2015, there were around 63,000 Polish citizens living in Spain (15,211 in Madrid) and in 2017 - around 52,000. ${ }^{4}$ Some sociological research describe the history of Polish community in Spain from the $16^{\text {th }}$ century up to 2007. As Mikołaj Stanek and Elżbieta Sobczak ${ }^{5}$ write, since 1980, Polish community started to grow because of the influx of economic migrants. After Poland's accession to the EU in 2004, we can observe the increase of the Polish community - the biggest number $(86,324)$ of Polish citizens in Spain was noted in 2010 by INE. Most children of Polish origin living in Spain probably belong to a group of the second generation of migrants. ${ }^{6}$

The United Nations Department of Economic and Social Affairs (UN DESA) data show that the number of people aged 19 or under living in a country other than the one where they were born rose from around 28 million in 1990 up to 36 million in $2017 . .^{7}$ The perspective of migrating children has been rather nonexistent in both childhood and migration studies for many years. ${ }^{8}$ Anne White et al. ${ }^{9}$ writes that research on children and migration has often focused on the processes of integrating children with the "home" community and their future as adults, apart from the children's direct experiences with the host country during their childhood. It is worth noting the perspective of children from the so-called 1.5 generation who left for the country of emigration in childhood. They speak the language of the country of migration fluently but still feel a close bond with the country of emigration. Another group is the second generation of migrants. These are the people who were born in the country of their parents' emigration. For them, the country of their parents' origin would be the country of emigration if the parents decided to return..$^{10}$ The decision to change the place of residence is always in the hands of adults which was also demonstrated by the studies conducted in Poland on a group of children from returning families. ${ }^{11}$

Migration is associated with the separation from family members and friends which is an additional factor affecting the child's functioning. One of the most recent studies on the impact of experiencing different types of migration from birth to

4 http://www.ine.es/ [access: 27.05.2019].

5 M. Stanek, E. Sobczak, "Polacy i Polonia w Hiszpanii na przełomie XX i XXI wieku," Studia Polonijne 2007, vol. 28, pp. 215-227.

6 Ibid., pp. 220-223.

https://migrationdataportal.org/themes/child-and-young-migrants [access: 27.05.2019].

8 M. E. Hatfield, "Children Moving 'Home'? Everyday Experiences of Return Migration in Highly Skilled Households," Childhood 2010, vol. 17, issue 2, pp. 243-248.

9 A. White, C. Ní Laoire, N. Tyrrell et al., "Children's Roles in Transnational Migration," Journal of Ethnic and Migration Studies 2011, vol. 37, issue 8, pp. 1160-1163.

10 M. Boyd, S. Tian, "Educational and Labor Market Attainments of the 1.5 and Second-Generation Children of East Asian Immigrants in Canada," American Behavioral Scientist 2016, vol. 60, issue 5-6, pp. 705-707.

${ }_{11}$ H.Grzymała-Moszczyńska,J.Grzymała-Moszczyńska,J.Durlik,P.Szydłowska,(Nie) tatwe powroty do domu? Funkcjonowanie dzieci i mlodzieży powracajacych z emigracji, Warszawa 2015, p. $42,59$. 
14 years of age on later life was carried out in Denmark. ${ }^{12}$ This longitudinal study covered people born between 1971 and 1997. The results indicate that relocations in early and late adolescence have a negative impact on the mental functioning of these people in later periods of life. ${ }^{13}$ The increased risk was observed for all the tested results, with the excess risk referring to persons exposed to multiple or single transfers during the year. Studies on a group of Polish children living with families in Scotland ${ }^{14}$ point to the translocal ${ }^{15}$ identity of children who change their place of residence.

Regardless of the type of migration, children who change their place of residence are at risk of violating human rights. Although children who do not have documents are potentially at a higher risk, having documents does not necessarily guarantee equal access to resources, as the migration situation still exposes them to discrimination and language barriers. ${ }^{16}$ Research carried out in Polish schools by the AntiDiscrimination Education Society ${ }^{17}$ indicates that one of the reasons of the unfair treatment of their peers at school is the migration experience. Schools are important places for socialization and the development of peer relations ${ }^{18}$ therefore the situation at school influences the process of the cultural adaptation of a child to a new country. Many Polish children who live abroad attend Polish schools. Polish-language education abroad is provided by The Centre for the Development of Polish Education Abroad (Ośrodek Rozwoju Polskiej Edukacji za Granicą - ORPEG). It provides and supports supplementary teaching in School Consultation Points (Szkolny Punkt Konsultacyjny - SPK) ${ }^{19}$ and in schools run by NGOs. It offers on-line Polish language courses, assigns teachers to work abroad and supplies textbooks. The number of these

12 R. T. Webb, C. B. Pedersen, P. L. H. Mok, "Adverse Outcomes to Early Middle Age Linked with Childhood Residential Mobility," American Journal of Preventive Medicine 2016, vol. 51, issue 3, pp. 291-292.

13 Ibid., pp. 292-296.

14 M. Moskal, "When I Think Home I Think Family Here and There': Translocal and Social Ideas of Home in Narratives of Migrant Children and Young People," Geoforum 2015, vol. 58, pp. 147-151.

15 According to Appadurai (1995, 1995, for: M. Moskal, "Polish Migrant Youth in Scottish Schools: Conflicted Identity and Family Capital," Journal of Youth Studies 2014, vol. 17, no. 2, pp. 279-291, p. 144) the concept of translocality describes ways in which local communities are expanded through the mobility of their members. According to this approach, local communities remain the source of the importance and identity of mobile members.

16 J. D. McLeigh, "Protecting Children in the Context of International Migration: Children in Migration Require Greater Protection from Violence, Exploitation, and Discrimination," Child Abuse \& Neglect 2013, vol. 37, issue 12, pp. 1057-1058.

17 M. Chustecka, M. Dymowska, E. Stoecker, "Dyskryminacja w szkole oczami młodzieży na podstawie wywiadów grupowych z uczennicami i uczniami gimnazjów oraz szkół ponadgimnazjalnych" [in:] Dyskryminacja w szkole - obecność nieusprawiedliwiona. O budowaniu edukacji antydyskryminacyjnej $w$ systemie edukacji formalnej $w$ Polsce, eds. K. Gawlicz, P. Rudnicki, M. Starnawski, Warszawa 2015, p. 104.

${ }_{18}$ M. Bak, K. V. Brömssen, "Interrogating Childhood and Diaspora through the Voices of Children in Sweden," Childhood 2010, 17(1), pp. 113-128; D. Devine, "Mobilising Capitals? Migrant Children's Negotiations of Their Everyday Lives in the Primary School," British Journal of Sociology of Education 2009, vol. 17, issue 1, pp. 521-535.

$19 \mathrm{http}: / /$ www.orpeg.pl/index.php/szkolynaswiecie/szkolne-punkty-konsultacyjne [access: 27.05.2019]. 
schools is only estimated due to the fact that the entities establishing and running these institutions are not obliged to register officially their activities in Poland. It is believed that no less than 40,000 pupils worldwide use the Polish language in this organizational form (Ministry of Foreign Affairs, 2012). This educational project allows not only to learn the Polish language, but also, to a certain extent, grants the implementation of the core curricula of the Polish education system such as history, geography or religion. In addition, these schools often become a meeting place for the Polish parents and children. According to The Centre for the Development of Polish Education Abroad (Ośrodek Rozwoju Polskiej Edukacji za Granicą, ORPEG ${ }^{20}$ ), there are 22 registered Polish "Saturday" Schools in Spain. It is difficult to assess the number of students as schools are not obliged to report such figures. As can be seen, Polish children often function in two environments and two education systems even though the second one is less absorbing because of the frequency of classes (twice a month or once a week). How do they experience the processes of cultural adaptation, then?

The process of cultural adaptation was initially described as a sociological process based on a cultural change, resulting from a meeting of representatives of different cultures. ${ }^{21}$ The most well-known model of acculturation is the Berry's model. ${ }^{22}$ It distinguishes four acculturation strategies undertaken by emigrants: integration (adopting a host culture while maintaining the culture of origin), assimilation (rejecting the culture of origin, maintaining of the host culture), marginalization (rejecting of the culture of origin and host culture) and separation (maintaining the culture of origin, rejecting the host culture). The Concordance Model of Acculturation designed by Piontkowski ${ }^{23}$ and the Interactive Acculturation Model designed by Bourhis et al. ${ }^{24}$ are based on Berry's model and added some important points such as using the perspective of both host and migrant groups. The RAEM model ${ }^{25}$ was originally designed to measure adaptation strategies undertaken by adults. However, it has been adapted to measure the acculturation strategies of children and adolescents. ${ }^{26}$ This model

${ }^{20}$ http://polska-szkola.pl/db/web/database/baza-danychszkol?field\%5B1578\%5D=Hiszpania\&quer $\mathrm{yString}=\&$ dateFrom $=\&$ date $\mathrm{To}=[$ access: 27.05 .2019$]$

${ }_{21}^{2}$ P. R. Smokowski, R. Rose, M. L. Bacallao, "Acculturation and Latino Family Processes: How Cultural Involvement, Biculturalism, and Acculturation Gaps Influence Family Dynamics," Family Relations 2010, vol. 57, issue 3, pp. 29.

22 J. W. Berry, "Immigration, Acculturation, and Adaptation," Applied Psychology: An International Review 1997, vol. 46, issue 1, pp. 5-34.

${ }^{23}$ U. Piontkowski, A. Rohmann, A. Florack, "Concordance of Acculturation Attitudes and Perceived Threat," Group Processes \& Intergroup Relations 2002, vol. 5, issue 3, pp. 221-232.

24 R. Y. Bourhis, L. C. Moise, S. Perreault, S. Senécal, "Towards an Interactive Acculturation Model: A Social Psychological Approach," International Journal of Psychology 1997, vol. 32, issue 6, pp. 369-386.

25 M. Navas, M.C. García, J. Sánchez, A. J. Rojas, P. Pumares, J. S. Fernández, "Relative Acculturation Extended Model (RAEM): New Contributions with Regard to the Study of Acculturation," International Journal of Intercultural Relations 2005, vol. 29, issue 1, pp. 21-37.

26 L. López-Rodríguez, B. Bottura, M. Navas, T. Mancini, "Acculturation Strategies and Attitudes in Immigrant and Host Adolescents: The RAEM in Different National Contexts," Psicologia sociale 2014, no. 2, pp. 133-157; T. Mancini, B. Bottura, "Acculturation Processes and Intercultural 
is very complex. First of all, it assumes that people can adopt different acculturation strategies in different spheres of life. Moreover, these spheres were divided into central (adults consider as important family values and religion; children believe in family, religious beliefs, traditions and practices) and peripheral ones (adults: work, politics, social relations, economics; and children: school, ways of teaching, things that teenagers buy, how they spend money or in which currency they save, relationships with peers from the same country of origin and their peers from the country of emigration). In addition, this model ${ }^{27}$ allows comparing the perspectives of both the receiving and the arriving groups. Another strength of this model is the ability to analyze the assessment of undertaken acculturation strategies and the preferences of the social actors (arriving and hosting communities) towards acculturation strategies undertaken by guests. This allows the distinguishing of the real and ideal plane of acculturation. The first deals with how the acculturation strategies are perceived and described by the behaviors of respondents and the second concerns the issue of the preferences presented in narrations or questionnaires about how it could be. In addition, using this model, the researchers controlled a number of psychosocial factors, such as favoring members of their own group or prejudice against other groups. Comparative studies ${ }^{28}$ conducted on a group of young people in Spain and Italy show that the teenagers from both groups prefer and practice the maintenance of their culture of origin in the central spheres, and the adoption of the culture of the host country in the peripheral spheres. The host groups observe the same pattern with one exception: Spanish adolescents observe the maintenance of the culture of origin both in peripheral and central spheres. However, when a host group is asked about their preferences, they declare that they would like the arriving group to adopt the culture of the host country in both spheres. To sum up, the authors suggest that the intergroup agreement between immigrant and host adolescents occurred more in peripheral areas, whereas there was a disagreement in central areas which is consistent with what other studies show. ${ }^{29}$ In this article, I would like answer the following question: What strategies of cultural adaptation according to the RAEM Mode ${ }^{30}$ undertaken in peripheral spheres do children and youth of Polish origin mention in their narrations?

To provide the answer to this question, I will present some preliminary results from the pilot study of the wider $\mathrm{PhD}$ project related to the adaptation strategies undertaken by the Polish child migrants living in Spain.

Relations in Peripheral and Central Domains among Native Italian and Migrant Adolescents: An Application of the Relative Acculturation Extended Model (RAEM)," International Journal of Intercultural Relations 2014, vol. 40, pp. 49-63.

${ }^{27}$ M. Navas, M.C. García, J. Sánchez, A. J. Rojas, P. Pumares, J. S. Fernández, "Relative Acculturation Extended Model (RAEM)," pp. 25-29.

28 L. López-Rodríguez, B. Bottura, M. Navas, T. Mancini, “Acculturation Strategies and Attitudes in Immigrant and Host Adolescents," pp. 143-153.

29 T. Mancini, B. Bottura, "Acculturation Processes and Intercultural Relations in Peripheral and Central Domains among Native Italian and Migrant Adolescents," pp. 55-61.

30 M. Navas, M.C. García, J. Sánchez, A. J. Rojas, P. Pumares, J. S. Fernández, "Relative Acculturation Extended Model (RAEM)," pp. 25-31. 


\section{METHODOLOGY}

\section{Research group}

Twelve people participated in the pilot study. One subgroup consisted of five children aged 10 to 15 (two of whom were brothers), who attended classes in a Polish "Saturday" school and the other group of five consisted of the children's parents. One interview was conducted with both parents. Four children had both parents of Polish descent, one child came from a mixed family: Spanish-Polish. In addition, an interview was conducted with a priest who works with the Polish community in Madrid and a history teacher working at a Polish "Saturday" school. The respondents agreed to participate in the study and were also informed about the possibility of refusing to answer questions. The consent to the participation of children aged 10-16 was given by both parents and children. In this article, only the results of the preliminary analysis of the interviews with children will be described.

\section{Procedure}

As part of the study, 11 semi-structured interviews were conducted. The starting point for each of the conversations was a set list of questions which the researcher could develop depending on the threads introduced by the examined person. ${ }^{31} 10$ individual interviews were conducted, and one was conducted with two parents at the same time. The interviews were carried out in the respondents' homes or in public spaces such as cafes and parks.

\section{Results}

The text aims to apply the RAEM theoretical model in order to assess and better understand the undertaken strategies of cultural adaptation in the peripheral spheres of life (schools, peer relations and consumer behavior) of a group of Polish children living in Madrid. I will start with the sphere most prominent in children's narrations which is the school life.

31 K. Stemplewska-Żakowicz, Diagnoza psychologiczna. Diagnozowanie jako kompetencja profesjonalna, Gdańsk 2009, pp. 67-70. 


\section{SCHOOL LIFE}

All the children who took part in the pilot study attend classes in Spanish schools and Polish "Saturday" school at the embassy of the Republic of Poland. It can therefore be said that their adaptation to Polish and Spanish culture in the sphere related to the school life takes place in parallel. The respondents declare a big commitment both in the life of the Spanish and Polish schools. A more important role is played by the Spanish school as students attend it every day, while their Polish classes take place twice a month. For some children, the period of adaptation to the Spanish school was stressful.

J: I was 7 or 8 and the first two years were terrible ... I could only say "Hola" or "hello" and the teacher gave me a notebook to write new words there. I could read a little ... I had additional language classes. For example, instead of math class, I used to go to the teacher's office where she showed me how to write, how to say it, how to say that. She helped those who could not speak the language yet.

Janek

$\mathrm{K}$ : I remember that I was so nervous that it would be difficult and I also remember that there was a board with Spanish names of the days of the week such as Monday, Tuesday.

Krysia

Children feel good in the Spanish school. They declare that they have colleagues there, usually Spanish or of foreign origin. It is difficult to assess whether, in the understanding of the RAEM authors, children acquire the Spanish customs by rejecting their own culture of origin, because none of the examined children had contact with another education system besides the classes in the Polish "Saturday" school. They were born in Spain or arrived in Spain when they were still in preschool. It can be assumed that they participate in the life of the school, establish relationships, actively participate in classes.

R: Yes, how do you like the Spanish school?

F: I feel good there because I have a lot of friends.

Franek

$\mathrm{R}$ : And tell me, are there many students from outside Spain in your class?

$\mathrm{K}$ : There are some like me that were born in Spain, but their parents are from somewhere else. There are a lot of Romanians, children from Africa, Ecuador, Peru, Uruguay, Paraguay, and China.

Krysia

It can be concluded that their narration suggests adopting an integration strategy because functioning in both environments is important to them. This fact it is also visible in the context of the Polish "Saturday" school, where children learn Polish but they speak Spanish to each other. Moreover, at the Spanish school they sometimes say something in Polish. 
K: I do not look Spanish. Sometimes, for example, I am talking in a Spanish school with my friends and all of a sudden, I start to speak Polish.

$\mathrm{R}$ : And how do they react to it?

$\mathrm{K}$ : They are surprised, sometimes they laugh, and sometimes they do not notice.

R: And tell me, do you like going to the Polish school?

Krysia

F: I do.

Franek

K: I feel better in the Polish school, because in the Spanish (school) there are many groups. One is "popular," in the other, some people are using the phones all the time, and in the Polish (school) I feel better, because the group is small, we sit all together and it is better for me.

Krysia

Children show great motivation associated with learning Polish as they attend classes in the Polish school on Friday afternoons. On the other hand, the Polish school seems to be a meeting place which helps in building relationships with peers. Children treat it as a duty, but also as entertainment or a pleasant environment.

R: I hear that you have won a contest lately.

$\mathrm{O}$ : Yes, in spelling! I was a runner-up and I got a special prize from the $5^{\text {th }}$ grade $\ldots$ (In the Polish school) I meet my friends.

R: So you like spending time there?

$\mathrm{O}$ : Yes, because there are always parties, performances and so on.

Olek

J: I always play there with friends, or something. I do not care if it's up to 9 p.m. or it's up to 7 p.m.! ... Sometimes I do not want to go there but I do and I am happy with that. I'm learning Polish, grammar. That's what you need!

Jan

For some children studying the Polish language is a challenge. Although they speak fluent Polish in everyday life, grammatical structures or specialized vocabulary is something new for them.

$\mathrm{K}$ : The Polish language is sometimes a problem for me. Sometimes, for example, I do not know. A teacher explains that there is a subject, a rule and I still do not know what it is because I learned it a long time ago. But in Spanish? I need it in Spanish.

Krysia

Some statements indicate that children have the opportunity to express themselves in a Spanish school, which may be a manifestation of supporting the integration strategy of cultural adaptation and the possibility of sharing the experience of being a bicultural person.

K: Most are nice and cool (teachers). The English teacher organizes different tasks, for example, once we had to make a presentation about us on the computer, and then you presented to everyone in class in English. Later this semester, we had to make a film that was 10-15 minutes long and then there was the Oscars ceremony. 
I also have been performing in theaters since kindergarten. I like this kind of activity. In the Spanish school, there was extracurricular drama classes and I loved them and I always enrolled. When I was little, I did not speak, I only acted, but now I also speak. In primary school what our educator came up with was organizing such a performance in front of other people at school and getting rewards.

Krysia

R: Did you teach your friends and colleagues Polish? Are they curious about it?

F: This friend of mine, a German friend, was a bit interested in it, but I did not teach him much.

Franek

While talking about Spanish school, children refer to discrimination. Some of the children reported that they themselves experienced verbal discrimination on account of their origin. It can be expected that the experience of discrimination may intensify the separation strategies, but this has not been observed in this research group.

O: He did not run fast, for sure. And the others were laughing at him. "Slow, slow!"...

$\mathrm{R}$ : And do teachers do anything in such situations?

O: No, no! They sit, eat something. They're just talking. They pay no attention to anything.

Olek

E: Well, they do not say this especially to me. I know I'm very white. I'm not tanned at all. Some say I have blue, green, gray eyes. And all Spanish people have either black (laughs) or brown ... Well, at the beginning they were laughing at my name. And I do not know why. I'm normal.

J: It depends. At first they tell me that I am Romanian, but I say that I am from Poland and they leave me in peace. Africans or Latin Americans are in a worse situation. I do not participate in it, because it's not good, but if you can laugh at something, we laugh... In primary school, I can say that I was king, because everyone knew me from elementary school in the $1^{\text {st }}$ class. At that time, I was playing football and I was playing very well, but it was no such situation that someone would laugh at me or at someone else.

Jan

Some schools use special strategies to involve students in order to counteract the discrimination and violence.

J: The teacher can write to the child's family and the family can write to the teacher. The teacher may give a red card, on which he will write that the student has behaved badly and a child can be suspended from school, for example, for three days. You have 3 or 4 chances before you have to give that card to parents to sign and bring it back. After three times you are expelled.

$\mathrm{K}$ : They use a lot of names, but just as jokes. Or if there is a conflict between two people, it is solved and then they laugh about it together ... (Teachers) pay attention, but I have not seen such a terrible situation and I think that they would react ... At the beginning of the year I was chosen as someone who helps others who have a problem. Well, there are always two or three such people in the class ... The teacher prepares us by telling us before the person comes that, for example, a girl from Venezuela will come tomorrow. We are responsible for showing her the whole school and making friends with her. 
It can therefore be concluded that the Polish children, operating in both contexts Polish and Spanish, describe their behaviors as undertaking a strategy of integration, that is, maintaining their own culture and adopting the culture of the host country. On the other hand, the possibility of integration with the Spanish environment can be questioned, as most of the children attending the schools of respondents are also foreigners so if they make friends only with other foreigners it could be interpreted as undertaking the separation strategy within the group of immigrants. In the following section, I will focus on the issue related to the adaptation to the peer environment.

\section{PEER RELATIONS}

During the adolescence period, a group of friends is a more important reference group than parents. The group of people with whom children maintain relationships outside school are mostly Spanish people or other foreigners.

J: (I meet) more often with Spanish people! I see them on the street, we talk and so on, we make movies in English, we meet and record movies!

O: My best friend is Viktor! He was also in my old school, now I'm in the new one.

Jan

R: Is Viktor Spanish or Polish?

O: Spanish, he also has an older sister.

Olek

Children also keep in touch with their peers in Poland through skype, Facebook or mobile phone.

J: I have phone numbers, Facebook, and besides, when I play these computer games I write sometimes with them, sometimes we can talk for a while. I have a friend from Poland who I have known since childhood! He is two years older than me but we have known each other since we were born.

$\mathrm{R}$ : And here? Do you also have very close friends?

J: Not so close. I have friends that I trust, that I like and meet, but these are not friends for whom I would jump into the fire.

Jan

Poles meet children in Polish schools, but because of the large distances between places of residence, they say they do not meet with them in other circumstances, despite the fact that they declare such a need and willingness.

J: (In the Polish school) I know everyone, easily. I'm saying hello to everyone, bye. Let's talk or something.

Jan

E: I have friends. Recently, a Polish girl has come in and she has lived here for 5 months, her name is Magda. She cannot speak Spanish. I teach her a bit of Spanish and she teaches me Polish. I do not see her outside school. 
R: Would you like to?

E: I would.

F: I have a lot of colleagues who come from Poland.

R: And you have a friend in the Polish school, a close person?

F: No, because they live far away.

Franek

Referring to the issue of the peer relations, it could be said that Polish children talk about adopting an assimilation strategy. This is due to the fact that most of their friends at school and outside school are of Spanish or foreign origin. On the other hand they meet Polish peers in the Polish "Saturday" school but they do not meet them outside the school building because of their parents and long distances between their places of residence. They declare, however, that they would like to meet with them, which may indicate the fact that in the ideal plane they would like to adopt more their culture of origin by maintaining more contact with Polish peers.

\section{CONSUMER HABITS}

Consumer habits are another peripheral sphere of acculturation. This sphere includes, among other consumer products, types of entertainment or purchased items. It may seem that parents have a big impact on the strategies which their children undertake in this area by the way they use money for their children's leisure activities. Most often, boys play football in their free time or they get involved in playing with Lego blocks, which is characteristic of both Polish and Spanish culture so we cannot judge the acculturation strategy according to those behaviors. Girls dance or swim.

E: I like swimming and horse riding the most. When I return to Poland, I always ride a horse.

J: Yes, I used to play football in clubs. First, I played as a goalkeeper for three years, so I have my hands practiced. Later, I played a year in a Barcelona football club as a striker. It was good for me, but later I gave up, because I was going to a junior high school.

F: We go to the cinema, we play paintball sometimes.

Jan

Franek

Children also play computer games, which is also a possibility to keep in touch with their peers in Poland.

J: I play with people, we play with friends for fun. My friend has a channel on YouTube, sometimes we record something. In Spanish, not Polish. And then there are the Poles I play shooting games with, and we normally talk, we talk, we laugh.

Jan

Some children watch Polish TV and Polish films at home. They do not want to watch Spanish movies. In this aspect, and according to the behavior of using the media, the real and ideal sphere of acculturation overlaps. It can be said that the 
behaviors described by the children suggest undertaking the separation strategy of acculturation - maintaining one's culture and rejecting the culture of the host country. In addition, they declare that they read Polish books more often.

R: And tell me, your parents said that at home you only watch Polish TV.

J: Yes and we speak Polish.

R: And would you like to watch Spanish TV?

$\mathrm{J}$ : Not really. There is no translation of, for example, the English version, there is no original sound from the movie. I do not like watching TV like this all the time. It's better to listen and talk. Besides, it's not quiet.

Jan

R: Do you have any favorite Polish book?

E: The Lord of the Lion from Dorota Terakowska.

Ela

The exception was a boy whose one parent is of Spanish descent. He preferred films and reading in Spanish. He admits that for him the Spanish language is easier.

R: Do you watch any Polish films?

F: Rarely. We have a lot of movies here ... I like to read books in Spanish, and in Polish it's not easy for me, because there are so many words that I do not understand.

Franek

When it comes to the purchase of food products, both Polish and Spanish products appear in the kitchen, which can be evaluated as both adopting new culture and maintaining the culture of origin.

O: Yes! Dumplings! Potato pancakes and so on, but Spanish dishes are not bad either. My favorites - tortilla or patatas bravas.

Olek

The sphere of consumer behavior is an extremely difficult area for interpreting acculturation strategies. This is due to the fact that different behaviors which can be observed as a part of consumer behavior sphere can be categorized as undertaking different strategies. Referring to the preferences of watching Polish movies, children talk as if they were undertaking separation strategies, while in terms of food, the collected data show that families display integration strategies. Research on this sphere requires deeper analysis. An important fact may also be the impact of parents' preferences which largely determine the expenses of the family and purchased products. 


\section{DISCUSSION OF RESULTS}

So far, the RAEM model was used originally by the authors in the research of adult group ${ }^{32}$ The research involving migrant youth in Italy and Spain $^{33}$ showed that in the central spheres, immigrants tend to preserve their own culture and in the peripheral spheres they adopt the host culture. However, most of these conclusions were based on research using the quantitative methods such as a questionnaire. Therefore, the data presented in this article which were based on the qualitative methods are hard to compare because they provide different types of information.

The preliminary analysis of the qualitative data collected on the group of Polish immigrants shows that it is difficult to assess the strategies undertaken by immigrants in particular spheres. The described data is related only to a part of bigger research project. Despite this, it allows for some preliminary observations on categorizing and interpreting behaviors described by Polish children as undertaken adaptation strategies. The difficulties related to analyzing the qualitative data with the RAEM model, which is mostly used in quantitative research, can be observed. The observations coincide with the results of the research made in the Spanish and Italian ${ }^{34}$ group of adolescents saying that in the peripheral spheres, children talk about adopting the culture of the host country. On the other hand, the statements of young Polish people indicate integration strategies, because they maintain contact with both Spaniards and Poles who live in Poland and also participate in classes in both schools. In the sphere of peer relations, the differences between the real sphere and the ideal one is observed. In the real plane, children do not keep in touch with Polish friends in different environment from Polish "Saturday" School, but in the ideal plane they would like to be able to meet them outside the school context. The reason for this discrepancy may be the influence of the acculturation strategies adopted by their parents. This hypothesis needs further research which would focus also on the acculturation strategies undertaken by parents. Besides that, what we can observe is the discrepancy between the abilities and needs of Polish children and the content of classes in Polish "Saturday" schools. A better adjustment of the methods and the content of lessons to children's abilities may be needed. As children grew up in the Spanish society, the language which they mostly use is Spanish. That's why they sometimes do not understand specific words in Polish and sometimes have difficulties with following the classes for example about the grammar structure of Polish sentences. It means that more educational interventions should be implemented in the migrant societies - both related

32 M. S. Navas, P. Pumeras, J. Sánchez, A. J. Rojas, "El Modelo Ampliado de Aculturación Relativa (MAAR): Aplicación a nuevos colectivos de inmigrantes (rumanos y ecuatorianos)," [in:] Aplicación del Modelo Ampliado de Aculturación Relativa (MAAR) a nuevos colectivos de inmigrantes en Andalucía: Rumanos y Ecuatorianos, eds. M. S. Navas, A. J. Rojas, Sevilla 2010, pp. 77-99.

33 L. López-Rodríguez, B. Bottura, M. Navas, T. Mancini, "Acculturation Strategies and Attitudes in Immigrant and Host Adolescents," pp. 143-153.

34 Ibid., p. 151. 
to the way of teaching children at Polish "Saturday" schools and also about the value of maintaining the Polish language at home by their parents and the whole family.

When we look at the group of teachers working in Spanish schools they seem to be qualified to work with groups with migration experience. There are some procedures about how to get children involved in solving problems, how to prepare a class to welcome a new student. On the other hand, children report that some teachers do not react adequately when they see discrimination acts. The deeper analysis of overlapping spheres needs to be made as children frequently speak about a peer relation and school context.

The other reason why these results may not coincide with the original research could be the cultural differences between the research groups. The cultural context of Poland and Spain has some similarities such as catholic religion, even though the religious practices can be different. The population of migrants living in Spain (Morocco, Romania or Ecuador) and Italy (Africa, America, Europe, Asia) who took part in the original research was more diverse so there were people who grew up in cultures with different models of family, different type of traditions and other religions.

In addition, the qualitative data provides the information on specific behaviors which can be interpreted as the manifestation of undertaken adaptation strategy. Therefore, different behavioral practices within one sphere may be categorized as the manifestation of different acculturation strategies. The example of this can be the behaviors described in the sphere of consumer habits because some behaviors related to cooking can be qualified either as the strategies of adoption of the host culture and maintaining the culture of origin (integration), and others such as watching movies and reading books as separation manifested by maintaining one's own culture and rejecting the host culture.

A significant limitation of this study is a small research group as it is only a pilot study group from a wider research project. Moreover, the other limitations are the lack of wider usage of the model's possibilities such as the study of the host group perspective but also an analysis of undertaken acculturation strategies in the central spheres of life. The knowledge about both perspectives would allow to plan interventions related to cultural awareness for the needs of the arriving group. What needs further research is the comparison of parents' and children's perspectives on the adaptation strategies and discovering the factors in different spheres which support the undertaking of the integration strategy. Hopefully, the future results covering the whole project will provide clearer answers to those question and doubts as the RAEM model gives the opportunities to track adaptation strategies undertaken by adults and adolescents. Moreover, using the RAEM model with the qualitative approach also gives some opportunities to learn more about the migration context and about the variety of behaviors and their meanings related to cultural adaptation. 


\section{BIBLIOGRAPHY}

Bak, M., Brömssen, K.V., "Interrogating Childhood and Diaspora through the Voices of Children in Sweden," Childhood 2010, vol. 17, issue 1, pp. 113-128.

Berry, J. W., "Immigration, Acculturation, and Adaptation," Applied Psychology: An International Review 1997, vol. 46, issue 1, pp. 5-34.

Bourhis, R. Y., Moise, L. C., Perreault, S., Senécal, S., "Towards an Interactive Acculturation Model: A Social Psychological Approach," International Journal of Psychology 1997, vol. 32, issue 6, pp. 369-386.

Boyd, M., Tian, S., "Educational and Labor Market Attainments of the 1.5 and SecondGeneration Children of East Asian Immigrants in Canada," American Behavioral Scientist 2016, vol. 60, issue 5-6, pp. 705-729.

Chustecka, M., Dymowska, M., Stoecker, E., „Dyskryminacja w szkole oczami młodzieży - na podstawie wywiadów grupowych z uczennicami i uczniami gimnazjów oraz szkół ponadgimnazjalnych" [in:] K. Gawlicz, P. Rudnicki, M. Starnawski (eds.), Dyskryminacja w szkole - obecność nieusprawiedliwiona. O budowaniu edukacji antydyskryminacyjnej w systemie edukacji formalnej w Polsce, Warszawa 2015, pp. 79-131.

Devine, D., "Mobilising Capitals? Migrant Children's Negotiations of Their Everyday Lives in the Primary School," British Journal of Sociology of Education 2009, vol. 30, issue 5, pp. 521-535.

GUS, Główne kierunki emigracji i imigracji w latach 1966-2014 (migracje na pobyt stały), Warszawa 2014.

GUS, Informacja o rozmiarach i kierunkach czasowej emigracji z Polski $w$ latach 20042016, Warszawa 2017.

Grzymała-Moszczyńska, H., Grzymała-Moszczyńska, J., Durlik, J., Szydłowska, P., (Nie)łatwe powroty do domu? Funkcjonowanie dzieci i młodzieży powracajacych $z$ emigracji, Warszawa 2015.

Hatfield, M. E., “Children Moving 'Home'? Everyday Experiences of Return Migration in Highly Skilled Households,” Childhood 2010, vol. 17, issue 2, pp. 243-257.

López-Rodríguez, L., Bottura, B., Navas, M., Mancini, T., “Acculturation Strategies and Attitudes in Immigrant and Host Adolescents. The RAEM in Different National Contexts," Psicologia sociale 2014, no. 2, pp. 135-157.

Mancini, T., Bottura, B., "Acculturation Processes and Intercultural Relations in Peripheral and Central Domains among Native Italian and Migrant Adolescents: An Application of the Relative Acculturation Extended Model (RAEM)," International Journal of Intercultural Relations 2014, vol. 40, pp. 49-63.

McLeigh, J. D., "Protecting Children in the Context of International Migration: Children in Migration Require Greater Protection from Violence, Exploitation, and Discrimination," Child Abuse \& Neglect 2013, vol. 37, issue 12, pp. 1056-1068.

Moskal, M. 'When I Think Home I Think Family Here and There': Translocal and Social Ideas of Home in Narratives of Migrant Children and Young People", Geoforum 2015, vol. 58, pp. 147-151.

Navas, M. S., García, M. C., Sánchez, J., Rojas, A. J., Pumares, P., Fernández, J. S., "Relative Acculturation Extended Model (RAEM): New Contributions with Regard to the Study of Acculturation," International Journal of Intercultural Relations 2005, vol. 29 , issue 1, pp. 21-37. 
Navas, M. S., Pumeras, P., Sánchez, J., Rojas, A. J., "El Modelo Ampliado de Aculturación Relativa (MAAR): Aplicación a nuevos colectivos de inmigrantes (rumanos y ecuatorianos)," [in:] Aplicación del Modelo Ampliado de Aculturación Relativa (MAAR) a nuevos colectivos de inmigrantes en Andalucía: Rumanos y Ecuatorianos, eds. M. S. Navas, A. J. Rojas, Sevilla 2010, pp. 77-99.

Piontkowski, U., Rohmann, A., Florack, A. "Concordance of Acculturation Attitudes and Perceived Threat," Group Processes \& Intergroup Relations 2002, vol. 5 issue 3, pp. 221-232.

Smokowski, P. R., Rose, R., Bacallao, M. L., “Acculturation and Latino Family Processes: How Cultural Involvement, Biculturalism, and Acculturation Gaps Influence Family Dynamics," Family Relations 2008, vol. 57, issue 3, pp. 295-308.

Stanek, M., Sobczak, E., "Polacy i Polonia w Hiszpanii na przełomie XX i XXI wieku," Studia Polonijne 2007, vol. 28, pp. 215-241.

Stemplewska-Żakowicz, K., Diagnoza psychologiczna. Diagnozowanie jako kompetencja profesjonalna, Gdańsk 2009.

Webb, R. T., Pedersen, C. B., Mok, P. L. H., "Adverse Outcomes to Early Middle Age Linked with Childhood Residential Mobility," American Journal of Preventive Medicine 2016, vol. 51, issue 3, pp. 291-300.

White, A., Ní Laoire, C., Tyrrell, N., et al., "Children's Roles in Transnational Migration," Journal of Ethnic and Migration Studies 2011, vol. 37, no. 8, pp. 1159-1170.

\section{On-line Sources}

http://www.ine.es/

http://gmdac.iom.int/gmdac-migfacts-international-migration

http://www.orpeg.pl/index.php/szkolynaswiecie/szkolne-punkty-konsultacyjne

http://polska-szkola.pl/db/web/database/baza-danych-szkolhttp://www.unhcr.org/globaltrends2016/ 